\title{
A Cross-Society Study of Trust and Reciprocity: Korea, Japan and the L.S.
}

\author{
KisL:k ChO añd Byt:NG II. C.HOI

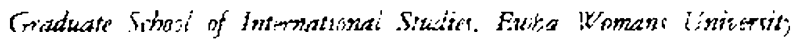

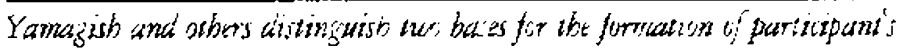

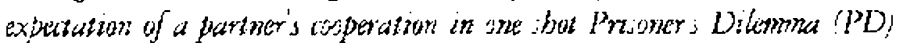

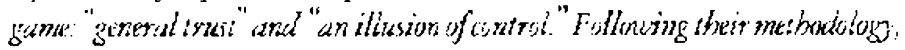

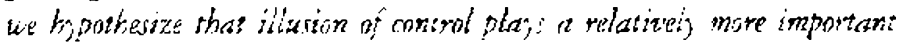

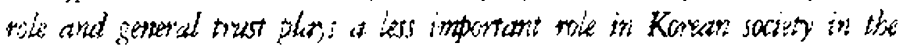
contexi of a ross-iacting comparison of Kaysa, Japan and the US. Thes

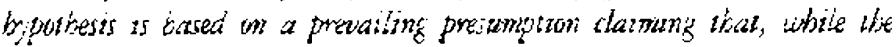

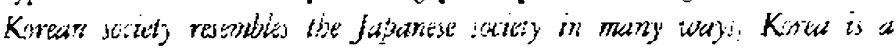

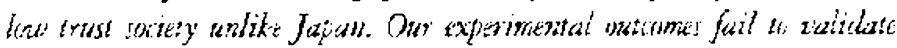

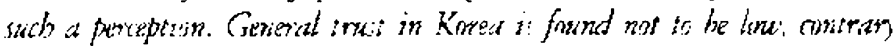

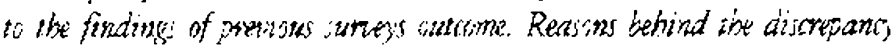
bututen sur findings and previour studites and perseptions are diswiksedí.
\end{abstract}

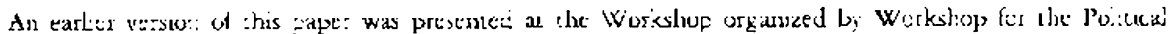

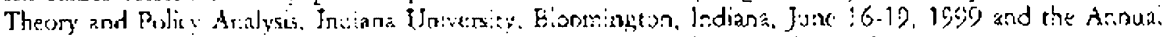

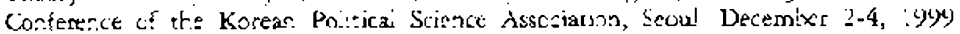

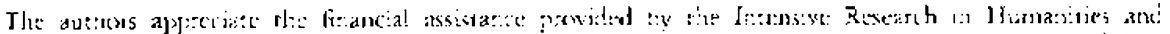

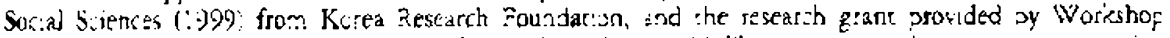

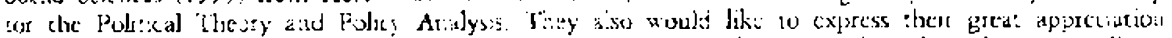

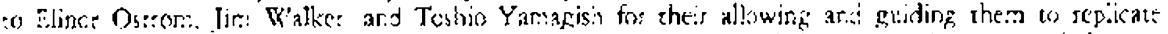

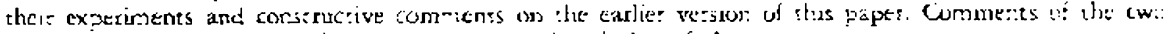

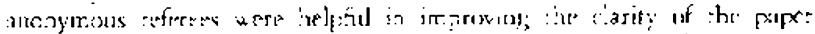

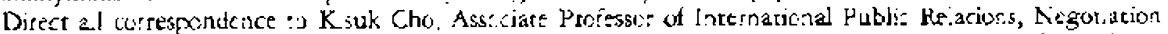

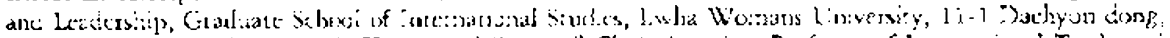

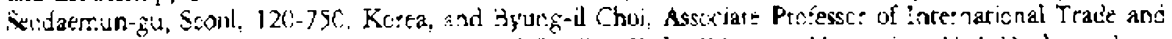

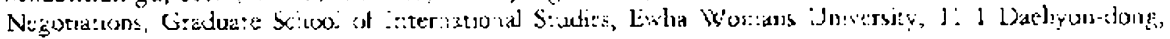

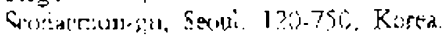




\section{INTRODUC'IION}

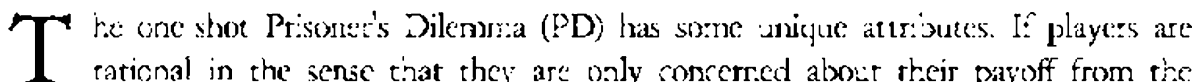
game, then rtoosing, no con:xation by each player is a unigue equilitbrium: This no coxperation equilibrius ciutcome is robust ever. if players are allowed to communicate pricr to their decisions, as long as the game is one-shct and each player has to choose his or aer course of action s.multareonsly without knowing the other player's cinoice. Althugh plaxers are germitcol to alk and they may azsec on the colectsve chore

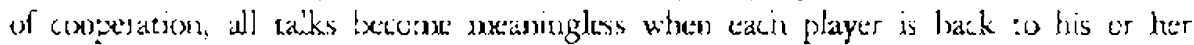

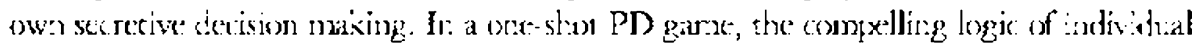
racionaly makes each opting for me coxperation a domirant strategy.

A urigue ectulibrimen of nc conperation in PD is indivishally rationa! but ner efficient from a society s perspective. if al, the players choose cooperaticn, each and every player car irrorove his or her faycs from the paysf associated with no cooperation; a!' tize players pavofi increases and no une is rorse off. Suck a move is possible if and only

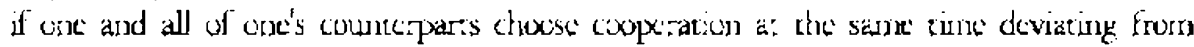

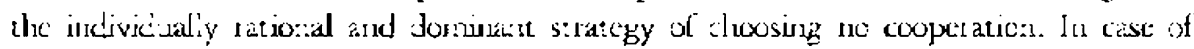

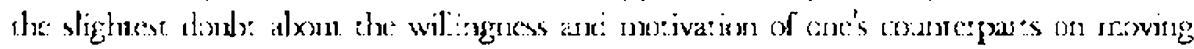
to such a collective clacice of cooperarion, one may ix mistaken in choosing coupxcraticn. Here comes the dile:nma

Despite the theoretica' peedistion of no conperation as a urique equiliorium in a one-sho: PD gans, nun-negligible instances of cooperation as an individual's accual strategy have been observed in expermental setungs anci in real wo:ld siruations.

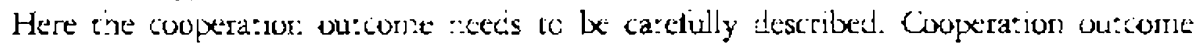

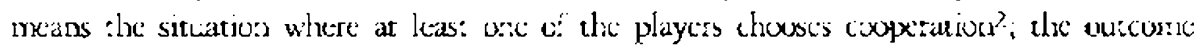

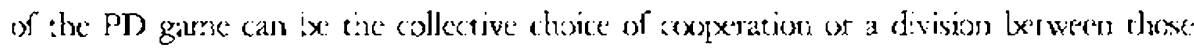

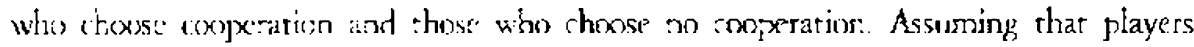
arc sational, cosperative outcome in a one-shot PD yame is only possible when plays's are cortident that their choice of cocperacion ail be reciprocared with the same shoice from their countcpars. In a ore-sh.ut PD game, where anonymois p'ajers are facing each cther, scich a reciprical move wolid be possible uncer wo circumstances: when at eas: one p'ayer trasts he: counterparts or wher: piayers pereese they can tontcol the decisicn of their counerpar:s.

\section{TRIST AND ILLIISION OF CONTROL}

An interpreation of the furmation of reciprociry in a une-snor PD game sas been

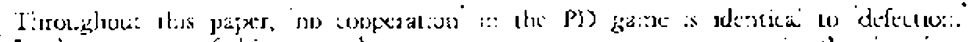

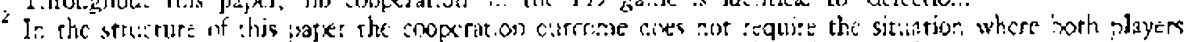

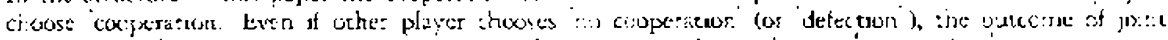

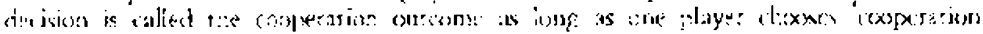


suggested by Watabe et al. (:996) and Surnere claborated by Havabio ot al. (1999)) Hayplasi a al. (1999) distinguisiec two bases for the expectation of a partner's cooperation in one-sher PD games - "general rnist" and "iliusian of control." Ising a variant formulation of one-shc: PD games, Hayashi et d. (140)9) argued that general crust and illusicn of control piay differert roles in societies, and eested a hy;othesis where illusicn of coatrol piays a relatively important role as a foundation for reciproca. expectation in Japanese soriety; whereas genstal tmust pays a more significant role is. American sociery.

In a serics of experimeateat.ons: Hayash et al. (:999) :ourd clear cy.dercet that particjpants treated PD gante as an asscrance gane and stoponded in a reciprocal manner. 'Then, what kind of role coes the thlusior: of contol play in an assurance garne?

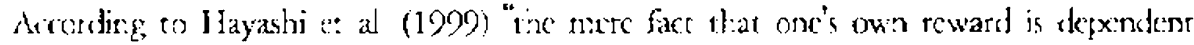
on the cecis ons of other group memixes rar trigge: the illusion of interdependency, disrezarcing the actua. lack of contimpercy among, members' decisior."

T. Yamagish and M. Yamagish (19\%4) distinginstand between trust and assurance in such a way tha: trist is as expectation of others bengn betavior under circumstances where people do not have cortrol over others In contrast, assurance is an expectatior. of o:hers lenign Leluavior within stasle and minaly commited relationships where

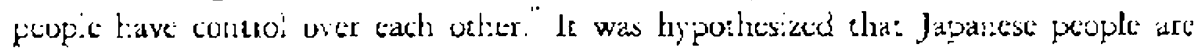

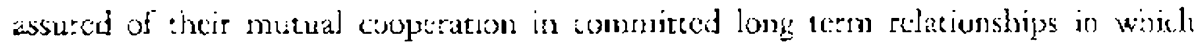

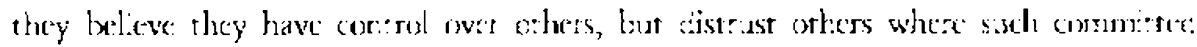
relat:onsinips do not exist. By contwast, rocperarior among Anericar participants secms built more on a general kind of tnist since s:ivey results have repeatedly showr. higher 'evels of tnist among Americans thas: among Japanese $(M$. Yamagishi and $T$. Yamagishi :989; T. Yamazishi 1988; T. Yamag.shi and M. Yamagishi 1994; Hayash: et a. 1982). Accordingly, the illusion of cortrol is predected to flay a more critica role among Jafanese partipants than among Anxercas: counterparts.

In arcier :o distirguish betwets genteral tnist and illision of cortrol. Watabe et al.

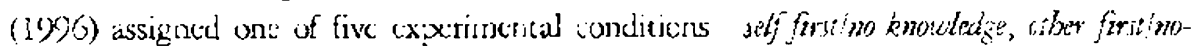

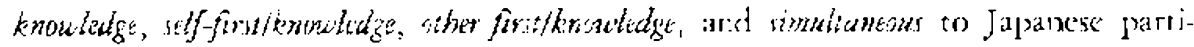
cipants. The fist four unditicas were seçucnrial PDe that differ an the order of the derisions made and the presence of informat:on ahou partmens decisions. Paricipants

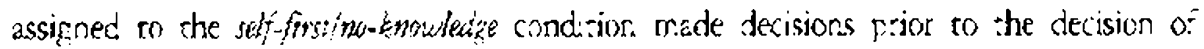
their parner They were informec, however, that the partser wov'd rot ze informed of tincir decision, prior to the partne: s cecision. The partner was intomed only tha: their pa:tner had already made a decisien. Correspondingly, paricipants in the viber-

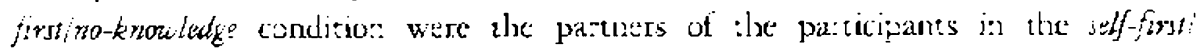

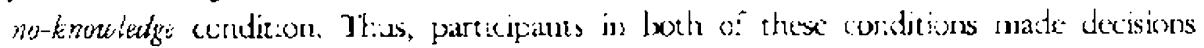
withou kncwirg their partucr's decision. This makes these nwo andirions logially the

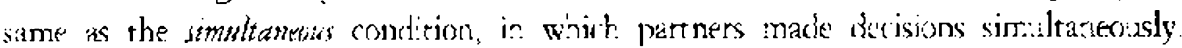

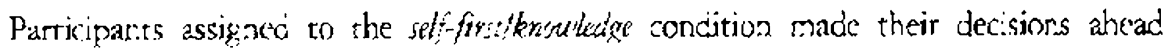
of their partne: Further, shey were informed that their partser woid be informed 
of theit decision, pricer to the partener's decision. Correspondingly, participastes in the

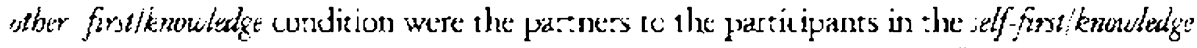
condition. The partuces in: this cond:ion were thus wold that either "your partner has decider: ro give yeu 500 yen' or "your partrer has decided not to give you 500 yer."

Different condit:ons manipulated in this exper:ment such as stif-firit/no-knontedxe, sther-

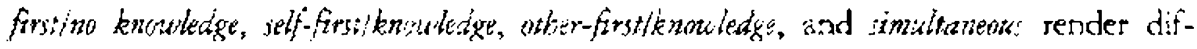
ferences in the perception of participants regarding an illiusio: of control (Watabe et al. 1996). Corsistent with Watàxe et al.(1996)'s arguments, expecimenta' results have shown that participants who found contrc.:ing a partner's inovice inpossitie in the wher fard/ro knowledge condition, cocperateci at a very low levell: $2 \%$ ) compared with

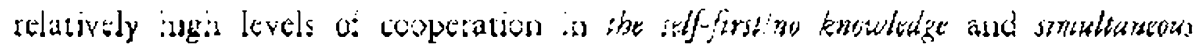

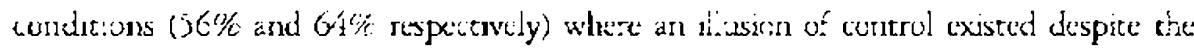

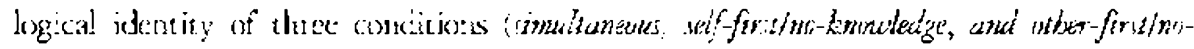
knouldatge concitis:as).

In this paper we excenci the methodology of Hayashi ct al. (1D97) to Korean soxicry. It is offen anguec thar Korean soxiery is a low rass level saxie:y, as exemplified in the na:jon-wice survey of Han and $A$ ish (1987) anc the cross-societal compazarive sticty of Fukuyama (1995). According :o the ourcomes of ine aatonal survey corducted by Auh is: $1984(\mathrm{~N}=1,551)$ and $: 995, \mathrm{~N}=1,481)$ eespectively, general distrus: among Korean peop.e mouncec to $82.5 \%$ and $81 \%$ who responded oos:tively

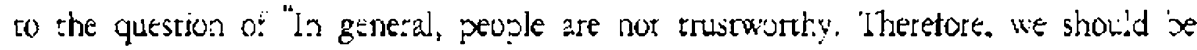
careful when contacting all sorts ce people." 3 These numbers reflect lewe: level of gencra. trast among Kurcans, whercas $26 \%$ of the Japanese sarnple $(\mathbf{N} \cdots 2,032)$ and

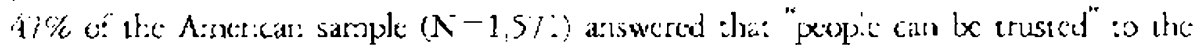

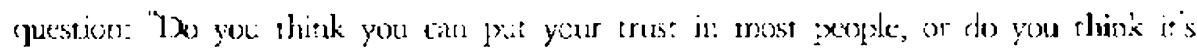
always lest on to or. your guarde",

Tising the methotslogy of Hayasin: $c:$ al. (1997), we arempter to es: the validiey of the hypothesis that goneral tust in Korean soxiery is ower, compared with Japan and the L.S. Many believe that Kcrear. sactety very munch resembles Japanese sxiery in the serse that the culture of collectivism, harmonization and conformity nun deep in each scciecy. In both sover es iong-term rela:ionships are ceef.y permeated in business activities, taking the form of lifetime empioyment, senicrity-jased pronotion anc vertically integrated bus:ness networks of ketritsu in Japan and thaksol no Korea.

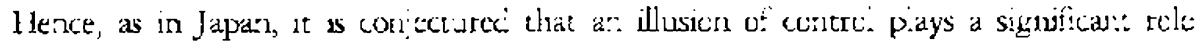
in Kortan secitty in accounting fo: the cnergence of cooperative txhavior. We well pu: this conjecture to ar: empirical iest apsolying the metaxiology of Fayashi, at al. $(1 \times)$ )

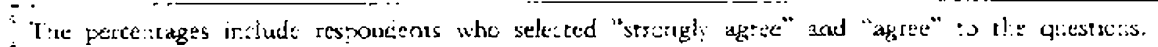

- Liayasini ct al (195\%)
} 


\section{'IESTING HYPOTHESES}

If a PD garne is perivived to be an assutance game by the participantes of uur experiments as Yamagish and his associates have argued, thete will $x$ a strong sense: of reriperciry in all three sxiet:es. When the players are informed about the partners' decision, there is no strong a protit zeason to assume that the pattern of reciprixal txhavio: - return conperation to the par:sers conpration and non-coperation to the partner's non-cooperation-will se sigrificantly diferent in a'l three societis. Hence, high .eve. of reciprocity is expected to occur amorg Korean players. It is hypothesized trat:

H1: Korean participants in the otherfint/knouledge condition will respond ir a reciprocal marne: to the partner.

In ixot: the Korean and Japasese societes, the culture of collex:ivism, harmonization

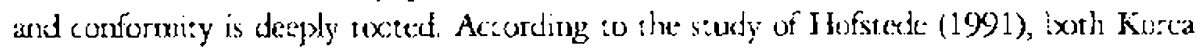
and Japan rank higt: in the index of collecivism, unecrtanty avoiklarce and hong term oriematicn. 5 These considerations ray leac one to coriectire that an illusion of conerol piays a sizniffar: ro.e in Korez sxiery in accounting for the emergence of coopera:ive behavior, as in the case of Japar. According to Hayast.: et al. (1997), illusios. of conirol payed a more siznifican: role in explaining cooperative behavior $n$ Japan vis-à-vis the L.S since Japan has murtured a s:able long-term. relationsh:p. Iherefore, our testing hypothesis is that illusion of control wil! play a najo: role in Korean socitety in accolntiry for the emergence of coopra:lve betavior, in contrast to thi. U.S.

A cautious approach, however, is requied since Korears ave recently experienced

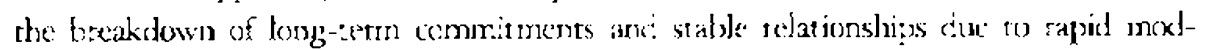

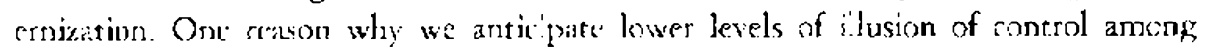
Korean participanes than Japancss participants is due to the massive popilation mobinity in Kotea io that in Japar. Airhough both Japan anc Korea experienced rajojd econcmic develcpment and usoarizat:on, the pace of and the extent of population movements from rura. to urzan areas in Korea far surpassed trat of japan. For instance, in 1981, when the ate of popula:ion mevement peakec un Japan, it was $5.9 \%$ and declined gradualy by $3.1 \%$ every year and reacined $5.3 \%$ in 2987. . Iho mob:.ity rate in korca peaked at $24.7 \%$ in 1983 and semained at a similar ras (22.6\%) in 1987 (Song 1997). The :and has readred the same pace wo to now snark:ng $21.8 \%$

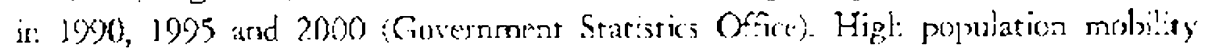
reduces a sease of ussuraree ia the commun:zy and we canne antecipate that pecple hold high illusion of control of cohers ir. such a fluid sociery. Hence the following hyporhests is derived.

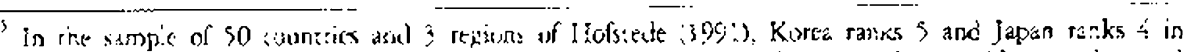

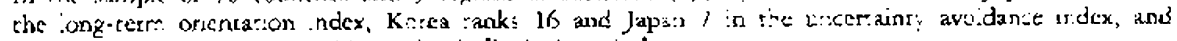

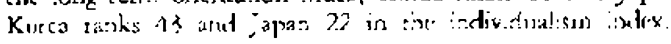


12: Illusion of control will play a more grominent role among Korean participants in accounsing for the emergence of cooperative behavion, compared to U.S. participants. It will play a weaker role, however, compared to Japanese participants since long-term stable relationships in Korea have deteriorated in the process of abrupt political change and rapid economic development.

1 Iypothesis 2 may ix sested in a stries of comparisons.

Hypothesis 2a: Korean participants will cooperate more in the self-fisilknowledge condivions than American partcipants, but less :han Japanese paricipants (because contrcl over the patne:s yehavior in this condition will be more important among Korean participants than among Amcrican participants, bu: less important than amcng Japanese par:icipants).

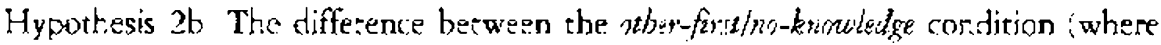

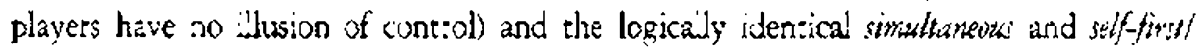
nt-kncilledige conditions will be geater among Koren participants than among Arrerican parricipar:s, jut smallet than among Japanese participants.

Hypothesis 2c: The difference between tre olf-instikntwedge soncition (where players have a expectation to influence the partaer's chnice) and the other-firstingknotuldge condition (where players are nor expected to have as i.lusion cf control) will be greate: among Kortan participants thar. that of Anerican participanss, but smaller than that of Japanese participants.

H3: Gencmal trust in Korea will be lower, compared with the U.S. and Japan

In the cther-fisstmo-knoultedige condtron (where ony general tmust is expected to :aduce

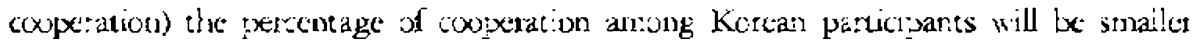
than that of bot: Aincrican and Japrantse participants. A prevading perception is that Korcan sceicty is a low trust level society Such a percegtion was attested by the nation wide survey of Harn and Auh (1987) and rchicet in Flikuy ama (1995). in a study

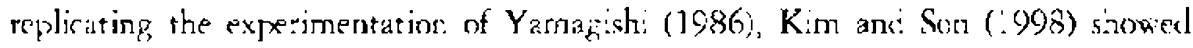
that, writhou: sanction, cooperation level was lower in Korcan society compared to Amencan society On the basis of these wots and a widely shared perception, we

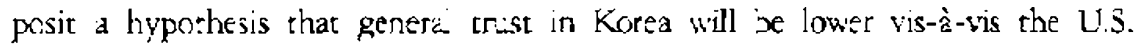

\section{EXPERIMENT DESIGN}

\section{Experimental Pratocol: Korea}

Each participane was macched with anociner participane and was asked to pay the 
PD game described above for the siudy conducted by Watabe et al, (19\%6). The ganne was flayed caly once. Each participant was randonly matched with a patner who was located in artotier room. Double blinis procedures were asced. That is, dexisions were anomymous to other paricipants and to the expcrimeme: The anonymity of divisions was introduced by the ase of two experimenters and rwo mom monitors. The role of one expe-imente: was to inceract with. the participar:s, while the othe: expermenter processec partic:parts' decisions.

Parcicipants. Participants were tecruited from introductory and intermedia:e-level ceusses in various fickds such as the humanites, soxial sciences, natural sciences and arts from. three Universities locarece in Sroul, Korea Yonsei I Iniversity (Spring 1999), Seopang, Inivers:ry (Fall 1999) and Joorgang, Lniversicy (Spring 2000) in three different time periods The roral number of paricipans wias 320.(212 males, 106 fernales and mo inknow:a). Monetay incentives were emshasized in the recnu-ment process.

Decision: Gane. The expelimental instourtoms were a tartful repication of those used in Watabe at al. (19)6). The original nestructions for the parricipan:s and the experimenters were translared !nto Korean. Partcipants were assigned to one of the five experimental condisiors descrixed be.ow.

Foliowing Watabe et al. (19\%), the l'D gance used an the experinent was cons:ructed iti the folowing way- Each paricipaur: was prorsisted 4,000 won by the experinenter

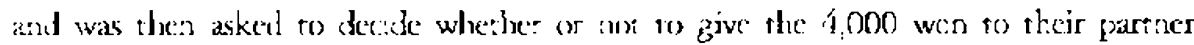
(a person randomly chosen from the participarts in the other room). When the participant gave 4,0000 won, the partner received 8,000 won. When the participant did nor give 4,C00 won, te/she coulc keep the 4,000 won plus another 8,000 won if his her parsne: chose to give his/aer 4,000 won. Therefore, both participants received 4,000 won when both decided not to give 4,000 won. Wher. one of the two participants decided nor to give 4,000 won, the one who kept the noney received 12,000 won anc the othe: who gave 4,000 wo: received rothing.

\section{Experimental Procedures}

Paricipanss were recruited, but in orcer os guasantee anorym:ty, aot randomly assigned into two grou?s? To elaporate, each group was recruited from the different c'assroors. Partcipants were seated apart each cthet upon arrival at the laboratories, and andoriy distriouced an cpaciue envelope that contained an ID card. lifiteer. to

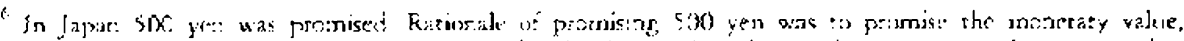
which enables the sctient to tave a lisht i.nch. Ccrsidesing the purshasing power of currency, that

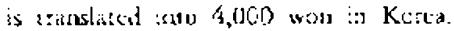

Sinse the experiments wers consurted pror to the micierm exam pe:inc; the experimenters had to come

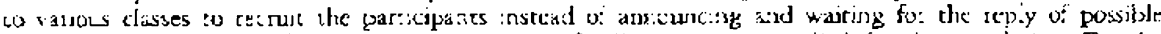

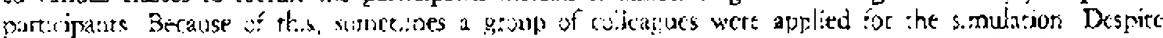

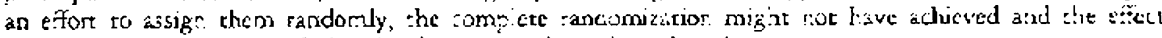

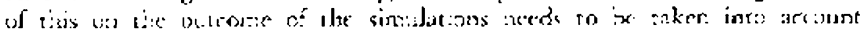


thrrey paricicantes participaced in any one expenumerital session.

Whacn all the par:icipants were reacy :o sarbicipate, the experimentet gave the following oral irscuctions. (1) This is an experinent of individuals decision making. (?) The experiment takes place in two rooms; earnings cepend not on'y on the individual's decision $n$ this room, bist also on that of a randomly matched participant in the orher room. (3) Monoy earned an this experiment wil. be paid in rash at the and of the exper:ment and earnings sill not je disclosed. (4) participants may ask questions at any time, but questions should be adiressed only to the experimenter in order to avoid pussiole concamnation)

Atter intreductory anno.ncements were ofered, participants sad the written insuructions explaiving powedires and the nature of the decisien gane. participants then were asked to answer a quic containisg fou giuestions about the gane to ensure

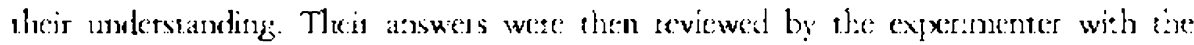
participiants.

Participants stomitred their decision form atter making lip their minds. The decision form was irserted in an erveloze afte: the ID number was writen inder the envelope cover and it was subritted to the expe:imente-. Participants kep: their iD cards Sor payoffs anci filled ou: pcst-experimental questionnaires.

in the sequential decision making, the expcrimenter collected decision. sheets from the room with the first group of players, shen moved to the room with tire second

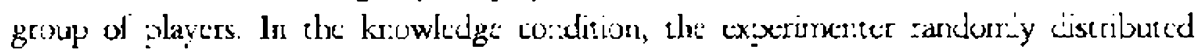
a decision slice of the first payer to the pariceparts in the second soom. In the no-krowledge condetion the experinenter eraphasized that aheir tandorsty chosen partuers bad alleaty made their cecisions to the scosnd movers.

When almost all the parric:pares Sinishec arswering the post-experimen: questionraires, they exchanged their ID cards with the!r earnings in a closed ervelope identified sitic their ID number. The entire exprinsent took ahout 45 minutes.

\section{FINDINGS}

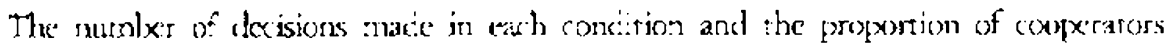
in each condition is epported in Table 1, which incorporates the findings of Hayzshi pi al. (1999),

\section{Strong sense of reciprocity in. Korea, Japan and the U.S.}

Al Korean, Japanese and Aruetican paricioants respunded ir: a reciprocal manner to the choice of theit fartacrs, re:urning cooperaticn to their parcuet s coperation

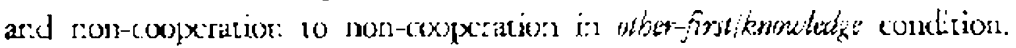

- Ore hunczed percenr of Korean participants did not cooperate in the other-first 
knowitedige condrion: when the partuer did rol coxpetate, ats compared to $88 \%$ of Japanese participants ank: $100 \%$ w: Ancrecar partic:par:s. The differences are apparer.ty staristically insignefitar:t.

- At the sane rime, $3 \%$ of Ko:can participants resporded by cooperating to a partner who coxperated, as rompared to $75 \%$ of apanesa particpants and $61 \%$ of American participants revealiag no statiscica, significance. 'T.uus, Kcrean participants are similar to Japanese and America: partic:paris in reciprocating the partners' chcice.

- Furthermore, pusc-experimencal sivey results manifest :hat the Korear. participants percerved the $? \mathrm{D}$ game as an assurance gane ist like Jimpancise coumeryars. 'Io a yastion "l low satustactury woLid $i:$ be 10 you if both yod and your partner gave 4000 wome" wish a resporse seale from ! fo: "lixt at a "? to 7 for "very anuth so,"

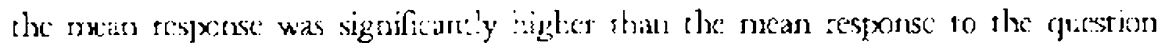
"How satistactory wold it be :0 you if your parener pave 4060 won and you did not?" (6.05 vs $4^{-7}:(319)=7.63, p<0(3)$. On the other hand, paticiparts respondex that no congeration would be more satisfactory that cooperation when the partner derecred $(2.30$ vs. $1.34:(319)=: 0.475,0<.000)$ rendering that the pose-experimercal suney resilts from the Korean participants are consistent with the results obrained from tine Japanese as well as American partipants. Iho experinetulal as well an questionzaire resules condi:an the hypothesis.

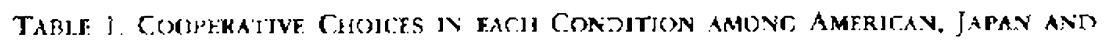
Koreai Participalits

\begin{tabular}{|c|c|c|c|c|c|}
\hline & Cunditiur: & $N$ & $\mathrm{~N}$, & Conperators & $\%$ Conperating \\
\hline is & Simr..slaa:scos:s & 50 & & 18 & 36 \\
\hline \multirow{11}{*}{ Japan } & sclr :Ast No knowlecigo & is & & 8 & 37 \\
\hline & 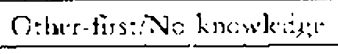 & 29 & & 11 & 38 \\
\hline & Srifinestow'eds:= & $\vdots 7$ & \multirow[t]{4}{*}{.. } & 18 & 56 \\
\hline & Otteet-f.stir & : 8 & & 11 & 6: \\
\hline & Other-fi:st $/$. ) & $: 3$ & & 0 & $\mathrm{i}$ \\
\hline & Simultaneou:s & 27 & & 15 & 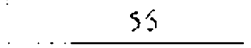 \\
\hline & Self-îrse No-knowlecige & 28 & & 18 & 64 \\
\hline & Other-firs-iNc-kn=wledge & 3 & & 3 & 12 \\
\hline & Sr:-Lir:s/K Juw ed $\mathrm{d}:-$ & 23 & & 1) & $8 ;$ \\
\hline & Utitus:astic & 20 & & 15 & 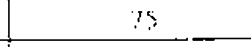 \\
\hline & 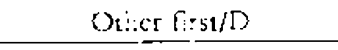 & .25 & & 3 & $1 ?$ \\
\hline \multirow[t]{6}{*}{ Kuscai } & Simnd1:atso:15 & 59 & & 28 & 46 \\
\hline & self irse No knowledpe & $1: 6$ & & ifo & 35 \\
\hline & Other-firs: Nokrodedre & 103 & & 13 & 42 \\
\hline & Set-frrsi/Krowitedge & 21 & & 11 & $5:$ \\
\hline & Dener-atest/C & $\therefore$ & & 8 & 3 \\
\hline & Otier-înstij & $: 0$ & & 0 & i \\
\hline
\end{tabular}




\section{No illusion of control in Korea}

\section{Hypothesis 2a}

- The coopration rate in ile self-firsiknowletige condinion among Korean participants was $52 \%$, which is similar to that of the Anxerican participants $(56 \%) y^{?}(1)-.07 ?$, $\mathrm{ns}$, bit significanty lower than that of the Japarkese participants (83\%) $\chi^{2}(1):-$ 4.62\%, $\mathrm{p}<.035$. Altheugh we predicted that the rooperation ratp among Korcans would be lower than that of the Japanese, the level was found to be far beiow the prediction and was not significantly different from that of Ametican participants. Honce, hypothesis 2a is not suppored, suggestang that there is no illusior. of cor.tol among Korean participents.

Hypothesis 2b

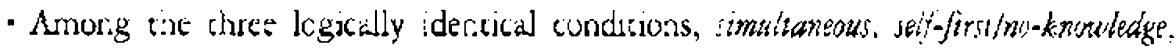

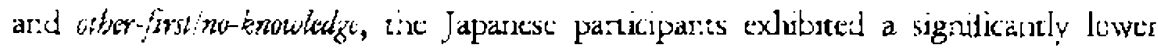
rate of coxperation $(12 \%)$ in stber-first no knowholye thas in the other two conditions:

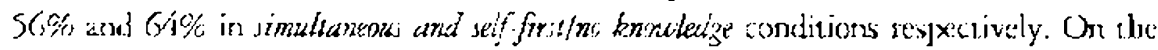
other hard, Anes ican parric ipants showed no statistically signifiean differeare among the three logically identical conditions $x^{2}$ (2) -0.21 , ns. The ate of copperation among Korean participants was $12 \%$ an the other-firsflno-knowiedge

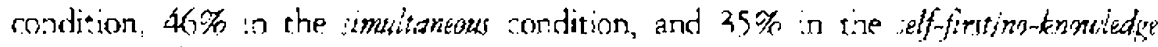
condition $\chi^{2}(2)=2.98$, ns. Compared with tice Japarese, the Korean case exhithirs no statistical differerces in the cooperation rate amor.g the logically identical conditions.

\section{Fyporhesis 20}

- The diffe:ence in the cooperatica rave between the self-first/krowiedge anc the o:therfirt/no-knowletge corditions (the two concitions that are assumed to create the maxumun and ininimurn eflect of illusien of contol) was much sualler (52\% versus $42 \%$ ) anong Keza: participanss ihar: anong Japarese par:icipants (83\% versus 12\%). The d:Scrence a:nong Korcan porricipants was cver: smaller eluan that among American participants (56\% versas 3,8\%). Hence, bypothesis $2 \mathrm{r}$ was not supportec mither.

A set of second hypotheses tes: reveals nc illusior of contrcl among Korean participants unlike our expectation. Korean participants behaved jus: like American particifants rather than Japanese part:opants. Onse an:riguing finding is that Korean participarats s:tuated in conditicus of the minimum level of i...asica of contod cooprated as much

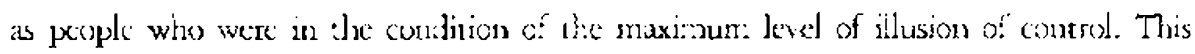
is direxty linked with the thired tyjotlesis. 


\section{General trust in: Korta is not low}

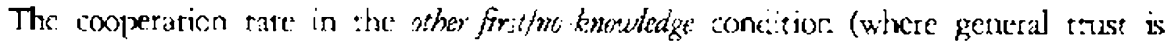
the only avaiable basis for torming an expectation that the pareaer would coopcrate) was higher among Ko:ear participarts (42\%) thar arıong Amenicar participarts (38\%) and Japarese particisan:s ( $12 \%) \gamma^{2}(2)=7.748, p<.025$. This result means the hypothesis claming tha: geners trast in Korea is lower, compared wit: the L.S. and Japan, is reiected in ois experiment.

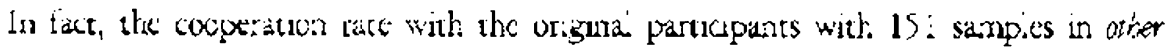
firtins-knonledge condition was sulssantialy higher (67\%) and tine difference between

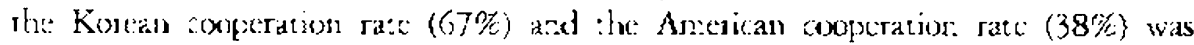
found to le staristically meaningful. We were sisjorious of the results. To test the robusmpss of such a firding, we increased our sample size to 320 from 151 and exper:aneared in differen: unversities. S:ill, we Sourd the highes coopeation sate among Korean participants of the :hree countries in this parictlar conciticn. Fitowever, in a larger sample there is no statistically nean!ngtul cifference setweer. the Korean coupe:ation rate and the Americar. cooperation rate.

in sumelar; Korean fartipants ecciprocated their parners choire just like L.S. and

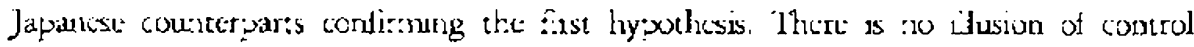
that infeucued participants decisions undixe Japanese counterparts disconfromeg the scconk: hypentesis. last, the level of general sust ameng Korean participants is nor lower comprad with the L.S. and Japanese participants. The fral anding is perhaps the rose striking and ateresting, in the light of exis:ing literature, in partirvat Han and Acin (1987), Kirr. and Son (1998) anc Fuxuyama (1995;.

\section{CONCLUSIUN}

The present experimental results valicate rlue jokea that Pl game is perceivec as an assurance gamo across differen culture displaying a gxat serse of reciparyy. On the Diner hand, o.r experimestal outcomes fail to valitate the prevaiting perception of Korean socier; as being a low toust socirty, by reviting inc second and third hypotheses pur forth in this srucy. Inlike the Japanese case, the Koreass have shown no Ilusion of contrc: Furthermore, a cypothesis that gereral level of trist is lower in Korea vis-à-vis the L.S. anc. Japan is not substar:iated.

Ohr experimer: on the Kurean zartccipants and the companson with the previous results of the iderctical experinkenc cinducted on the Ainerican and Japanese paricipants

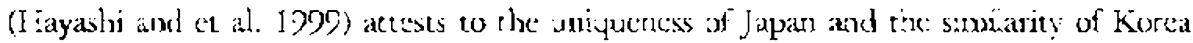
and the L.S. an social conflic: situation. Botn the Korean participants and the American participarts sinowed a remarkalie similarity in the: bxhavior in a variety of prisoner's dilemma situazion, whilc the Jacancse partcipants behaved differently in a statistically meaningfil way. 
Once of the reasons that we failed so find the illusion of control an Korca nught: bx fourd in the atsunt deterioration of traditicnal community in Korea partly due to rassive population movements. The enclave agricuirural rommunity faced a sudden cemise in the ace of modercization, ursanization, and irdus:riaization. The speed and scope of slich a social change in Korea was urparalleled in any other society; Korea is said to undergo the "co:densed mociernization" in the time space of one generation, whicis took a century in othe: scxicty. Durng the abnipt social charge, the culture of assurance nurtured in the stable :rasitional conimuzity has been eruded.

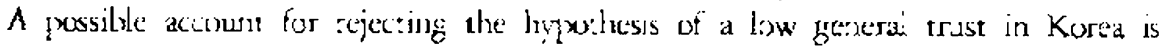

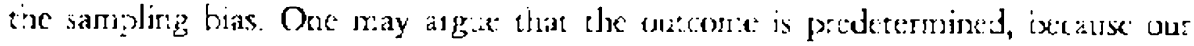
samples represcont mor thasting, grotaps of the pourlation in Korea. In the survey of Korea, hight trist has seen strongly correlated with higin echucarion and younger ayge (Aut 1999). However, this accour: is not convircing. Ohe needs to be reminded that post-experimental quest:onnaire residts of Koteas participaris condinted by Kim anc. Son (19)8) do rot specitica"y exhibir a higher leve. of general ruse compered to lapanese or Anerican perciciparts when usec responses un sirrilar items, Ka:ber, American

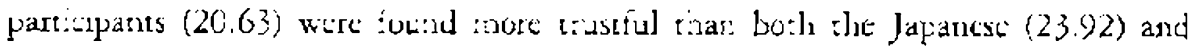
Koreans (23.26) (Yamagis! 1988, 26/; Kim and Son 19)8).

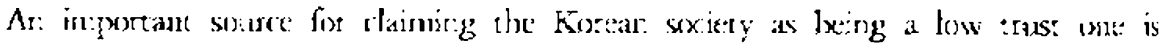

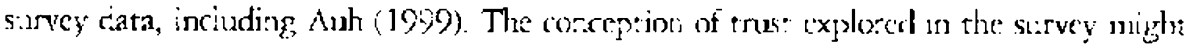
rot ' $x$ rhe same compared to tha was measured in this exporiment. While we pursuc

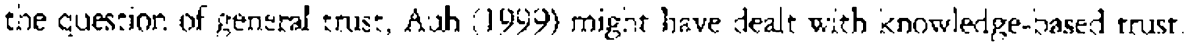
According to $T$ Yamagishi anc $M$ Yemagish: (1994, 139). "Whereas knowiedge-based thist is limited to particular ojjects (people or c.ganzations), gene:al rust is a beljef in the bernevolence cl human nature in genera." "Ihe survey might have simply captured

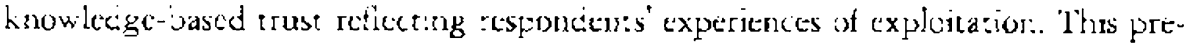
sumption is strengiloned by Auin (:909)'s tinding that trust arnong younger anci

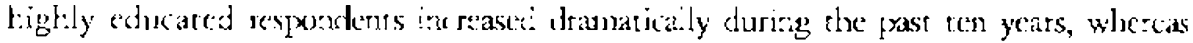
enust anomy older and less educarex prople derlined substantia'ly during the same pertixd

To properly measure getcral thist and andiuc: furthe: experimentat:on that dis:inguis:es different dimersions of rrust requires the design of a new survey questionnaire. We speculate that relaively high ieve. of gercra' tn:st annong Korean parcicipants, as we fourd in this pape:, might have resulted fron the measirement gap between experiments and surrey. The two differen: tools might have measured citferent cinensions of trust Glase: and et al. (2000) empirica...y distinguish two key components of social capital : custworchy and trusting belayior. The investigation of differest

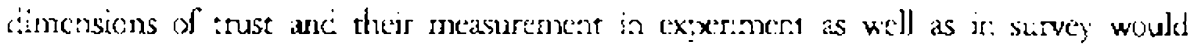

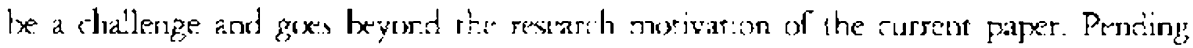
the complet:on of this task, we charn that a pxopuat axteption of Korca as a lon: roust scxiety vis-à-is Japan and the IJ.S. (F lkuyama :995 is a leading example) is rot substantiated. This discovery j:self is the sing! rost mportant esntribu ton of this paper. 


\section{REFERENCES}

Aul, Sov Ycung. 1999. "Continuity and Change in Korean Politicai Coilune." Korean Obiemer.

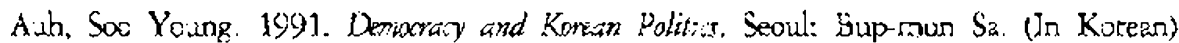

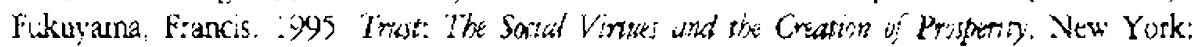
Fice laress.

Cijacere, Fatward I., David I. Iaibson, Juse $A$. Scheirixnan, ane Christ:at I. Somter.

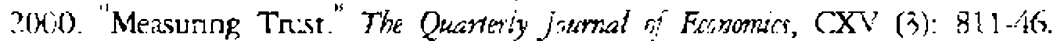

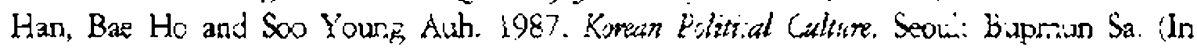
Kerear:

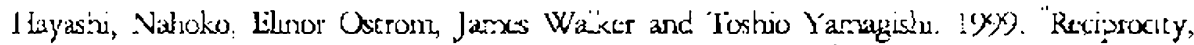

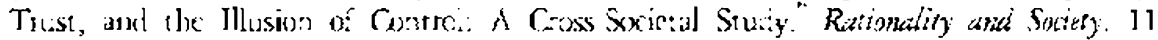
(1) 27.46

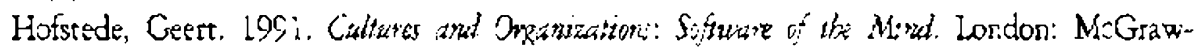
Hi:.

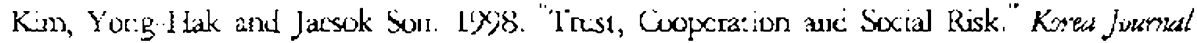
38: $154-189$.

Iae, Jaehyuck 1998. "Soxial Strucrure of Trist." Kmaan Socihog3 32. Summer): 311-35. (In Ko:ear:

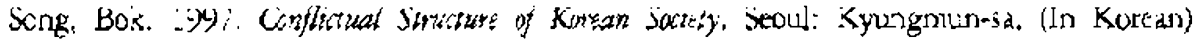

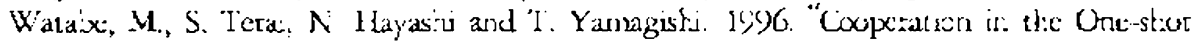

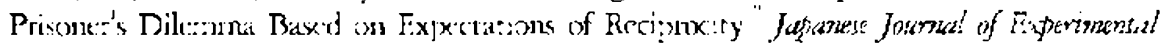
Sived Poyitoslog 36: 133-56.

Yamazist:, Toshic. 1788 "Tree Provision of a Sanctonning Systern in the L.S. and Japan."

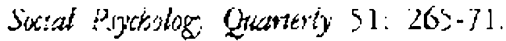

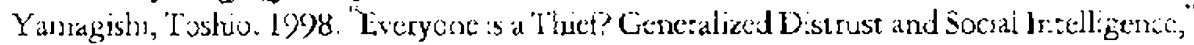

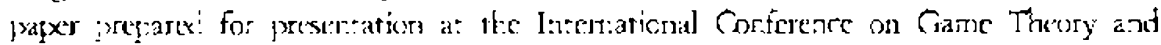
Intemational (ollatorasion, Kyoti, Japan, Fén. 24-2?.

Yamazist., Toshio, Masaso Kikıchi an: Noto:o Kosigi, :988. "Trust, Gullibiliry, and

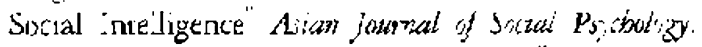

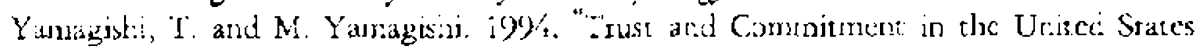
anc: Ja:an" Motizusion and Fomotion 18: 29)-66. 